ging over de gewelddadigheid in de Europese politiek, het streven naar verduidelijking van het internationale recht ten behoeve van de neutrale handel, de spanningen binnen het kabinet Van Bosse-Fock en de kabinetsformatie van 1871. Natuurlijk levert een studie over een nogal beperkt onderwerp als dit geen nieuw inzicht in de grote lijn van de Nederlandse neutraliteitspolitiek. Op grond van uitvoerig bronnenonderzoek bevestigt de auteur echter wat in andere studies al aan het licht kwam.

Doedens onderstreept in hoofdstuk 1 de samenhang tussen de Europese politiek, het Nederlandse buitenlandse beleid en de binnenlandse politiek. Zijn kijk op de mogelijkheden en beperkingen van het Nederlandse buitenlandse beleid in de daarop volgende hoofdstukken duidt er echter op dat hij de betekenis van de internationale machtsverhoudingen voor de positie van kleine landen als Nederland niet steeds op haar waarde schat. Hij is namelijk geneigd om geruchten over Bismarck's kwade bedoelingen met Nederland geloof te schenken en daaruit te concluderen dat Nederland in 1870-1871 gevaar liep ingelijfd te worden bij Duitsland. Daar Engeland aarzelde de regering in Den Haag bij voorbaat militaire steun toe te zeggen, veronderstelt de auteur dat Londen eigenlijk niets bijdroeg tot de handhaving van de bedreigde Nederlandse onafhankelijkheid. Voor de passieve, behoedzame Nederlandse neutraliteitspolitiek en het halfslachtige, zuinige defensiebeleid van Den Haag kan de auteur verder geen waardering opbrengen: alleen een gewapende onzijdigheid, gesteund door een dynamische diplomatie zou volgens Doedens de Europese positie van Nederland op adequate wijze hebben kunnen versterken.

Of een tweederangsstaat als Nederland destijds zelf zijn positie doorslaggevend kon verbeteren staat echter nog te bezien. Het lijkt integendeel alsof kleine mogendheden hun positie nauwelijks in positieve zin konden beïnvloeden en alsof de overblijvende staten van de tweede garnituur hun voortbestaan dankten aan het spel van elkaar doorkruisende en opheffende krachten in de internationale politiek. Daar gaven de eersterangsstaten geheel de toon aan. De Engelse versterking van de Belgische neutraliteit bijvoorbeeld beveiligde Nederland tijdens de Frans-Duitse oorlog in hoge mate - maar daar kon Den Haag niets aan doen, want Londen nam die uitermate positieve maatregel onder druk van de Britse openbare mening.

Er schijnt geen werkelijk gevaar voor een Duitse inlijvingspoging te hebben bestaan: Bismarck ambieerde zo'n expansie niet. Bovendien maakten de toenemende nationale tegenstellingen tijdens de Frans-Duitse oorlog een ouderwetse diplomatieke oplossing waarbij de twee belligerenten hun rekening vereffenden ten koste van België en Nederland, onmogelijk. Eigenlijk kan het nauwelijks verbazing wekken dat Nederland de FransDuitse oorlog overleefde. Doedens' overdrijving van de buitenlandse bedreiging en van de gevaren van de Nederlandse diplomatieke en militaire inertie maakt de gelukkige afloop van deze episode echter vrijwel onbegrijpelijk. Dat is jammer, want met historische mysteries is noch de diplomatieke geschiedenis noch het debat over de huidige Nederlandse buitenlandse politiek gediend.

C. A. Tamse

H. de Liagre Böhl, Herman Gorter. Zijn politieke aktiviteiten van 1909 tot 1920 in de opkomende kommunistische beweging in Nederland(Nijmegen: SUN, 1973, 317 blz., $f$ 12.50).

Sunschrift 66 is een Leidse dissertatie die de auteur op 28 februari 1973 de doctorsgraad heeft doen verwerven. Dit proefschrift verdient zonder twijfel de ruimere lezerskring die het in deze editie zal hebben. De Liagre Böhl heeft gedurende een aantal jaren studie ge- 


\section{RECENSIES}

makkt van de figuur van de dichter-politicus Herman Gorter. De vrucht hiervan is het onderhavige werk, dat niet alleen bijzonder goed leesbaar is maar ook een degelijk stuk historisch onderzoek vormt en als zodanig een belangrijke bijdrage levert tot de literatuur over de geschiedenis van het Nederlandse socialisme in de twintigste eeuw.

Gorter zelf heeft in een brief tijdens zijn laatste levensjaar (1927) getuigd, dat de 'glorietijd van 1910 tot ongeveer 1917 of 1918' het hoogtepunt van zijn leven vormde en daarmee is de keuze van de periode die de schrijver in zijn boek heeft behandeld gewettigd. De historicus kan zich niettemin afvragen hoe groot de objectieve betekenis is van de eerste periode van Gorter's deelneming aan de Nederlandse arbeidersbeweging, die van de jaren 1897-1909, vanaf zijn toetreding tot de SDAP tot aan de scheuring op het Deventer congres. De Liagre Böhl verwaarloost deze tijd waarin Gorter reeds zulk een onvervangbare plaats in de beweging was gaan innemen, niet geheel (in zijn inleiding met name), maar dit deel vormt toch slechts de aanloop tot zijn eigenlijke studie.

Gorter die als propagandist in woord en geschrift in de SDAP hoge roep genoot, die bovendien actief deelnam aan verkiezings- en andere acties (in 1903 was hij de succesvolle organisator van de staking in Groningen als vertrouwensman van het Comité van Verweer) en een tijdlang zitting had in het partijbestuur in de door Schrijver niet gereleveerde periode van marxistisch overwicht rond 1905, was vrijwel de enige prominente figuur van de Nieuwe Tijd-groep, die in 1909 met de Tribunisten meeging naar de nieuwe partij, de SDP. Aan zijn positiekeuze in het conflict van dit jaar besteedt de auteur veel aandacht met behulp van ten dele nog onbekend brievenmateriaal. Gorter moest enige aarzeling overwinnen alvorens hij definitief voor de nieuwe formatie koos, die voor hem de breuk met een aantal oude vrienden betekende.

Aan de activiteiten van de SDP nam de dichter in de aanvang als spreker op vergaderingen en als schrijver van artikelen en brochures levendig deel. Weliswaar viel reeds in 1911-1912 een eerste periode van afzijdigheid, waarin Gorter zich in eenzaamheid terugtrok te Bergen en ook met zijn gezondheid te kampen had. Deze situatie zou zich later herhalen en gaandeweg regel worden. Een belangrijke bron van informatie is voor De Liagre Böhl het dagboek van Gorter's vriendin Jenne Clinge Doorenbos geweest, waarmee exacte datering van gebeurtenissen mogelijk wordt. De relatie van de dichter van Pan met deze veel jongere vrouw heeft in zijn latere jaren ongetwijfeld een grote plaats ingenomen, maar ook een die hem van de kring van zijn oude medestanders als Henriëtte Roland Holst (die inmiddels ook de SDAP verlaten had) verwijderd heeft, naar men wel moet aannemen. Dit neemt niet weg dat Gorter in de jaren voor en na het uitbreken van de eerste wereldoorlog het standpunt van de Tribunisten ten volle deelde. Hiervan getuigt met name de verschijning van een van zijn belangrijkste en meest verbreide geschriften Het imperialisme, de wereldoorlog en de sociaal-democratie in 1914. Langzamerhand had zich in de Internationale een revolutionaire linkerzijde afgetekend, die zich van het toonaangevende centrum-marxisme, vooral vertegenwoordigd door Gorter's persoonlijke vriend Kautsky, distantieerde. Het was de invloed van de in Duitsland werkzame Anton Pannekoek, die de gedachten van de radicale linksen, met name Rosa Luxemburg, naar ons land overbracht. In de figuur van deze astronoom met zijn neiging tot onverzettelijkheid in principiële kwesties vond Gorter een nauwe geestverwant.

Opmerkelijk is dat Gorter zijn vriend in een brief van januari 1915 nog toevoegt: 'Denk jij niet altijd al te veel over Duitschland-alleen'? Het ging hier om de visie van Pannekoek als 'orthodox'-marxist, die in het hoog-kapitalistisch ontwikkelde Duitsland de grootste mogelijkheden voor de toekomst van het socialisme aanwezig achtte. Gorter had in zijn brochure over het imperialisme het verraad juist van de Duitse sociaal-democratie in 1914 
in de scherpste bewoordingen gegeseld als uiting van dezelfde slavengeest die de Duitse liberalen van 1848 gekenmerkt had. Deze zaak is van te meer belang in verband met de internationale conferentie van Zimmerwaldin 1915, waar de SDP ook was uitgenodigd maar ten slotte verstek liet gaan. De Liagre Böhl behandelt deze historie in het kort, zonder alle achtergronden volledig te peilen. De bezwaren van de Tribunisten moeten voor een groot deel berust hebben op de deelneming van Duitse centrumfiguren als Ledebour, dezelfde mensen die op internationale congressen voor 1914 het nemen van effectieve besluiten ten aanzien van de strijd tegen de oorlog, waarop van Franse en Engelse zijde herhaaldelijk was aangedrongen, hadden verhinderd. In de voorbereidingen van Zimmerwald speelde ter linkerzijde niet alleen Lenin, maar ook de Pool Radek een door De Liagre Böhl niet aangestipte rol. Eerstgenoemde waardeerde de Tribunisten over het geheel hogelijk sinds zijn eerste persoonlijke contact met hen op het congres van Stuttgart van 1907 (de opmerking op p. 75 dat dit eerst in 1909 te Brussel gelegd werd, is onjuist).

Op de achtergrond van de kwestie-Zimmerwald speelde in de SDP de beoordeling van de mogelijkheden der proletarische revolutie in Europa mee. Daarbij valt de vrij scherp anti-Duitse instelling in artikelen van Van Ravesteyn en uitlatingen van Wijnkoop op te merken. Gradaties van pro-geallieerde of pro-centrale gezindheid kwamen in alle politieke partijen van neutrale landen als Nederland voor. De Tribunisten hadden sinds de traumatische ervaring van 1914 blijkbaar bijzonder weinig vertrouwen in de Duitse sociaaldemocratie. Wijnkoop schetste in 1917 het rijk der Hohenzollern als het bolwerk van de zwartste reactie met sterk feodale trekken. Op zich zelf is dit volkomen zinnige taal, die men ook terugvindt in zijn brochure over de Russische en de Duitse revolutie uit 1919. Dat de Tribunisten weinig voelden voor internationale actie, lijkt mij echter een onhoudbare these: aan de conferentie van Kienthal in 1916 betuigden zij adhesie en zij verleenden ook steun aan Spartacistische activiteiten vanuit Nederland waarin onder andere de latere DDR-president W. Pieck betrokken was (dit kan niet alleen worden geduid als samenwerking met de Franse spionagedienst, zoals schrijver op p. 234 doet).

Gorter eclipseerde in de loop van 1915 weer uit het politieke leven van Nederland en vertoefde sinds de zomer van 1917 in Zwitserland, vanwaar hij de ontwikkeling der Russische revolutie volgde. Hoewel hij in de Tribune van december 1917 nog polemiseerde tegen Pannekoek's opvattingen inzake de vredespolitiek der bolsjewiki, werd hij toch door zijn groeiende vrees voor de overmacht van het Entente-imperialisme gedreven gaandeweg scherper tegen Wijnkoop en Van Ravesteyn stelling te nemen. Bijzonder afwijzend stond hij tegenover de denkbeelden van de Amerikaanse president Wilson, neergelegd in diens Veertien Punten. Hieronder was het zelfbeschikkingsrecht der volken, een eis die ook door de Russische revolutie aan de orde was gesteld, maar die door Gorter van de hand werd gewezen. Wie iets voelde voor Wilson's democratisch imperialisme, bezondigde zich aan 'internationaal reformisme', schreef Gorter in 1918. Toch was het deze Wilson, die tijdens de vredesconferentie van Versailles in 1919 een afgezant naar Moskou stuurde met concrete voorstellen, waarop Lenin positief reageerde.

Dat de SDP sinds 1918 zitting had in het Nederlandse parlement was een omstandigheid die de steile Gorter, altijd al wantrouwig tegen parlementaire manoeuvres van zijn vroegere partijleider Troelstra, maar matig kon bekoren. Het artikel 'Troelstra-Wijnkoop' dat hij in dit jaar in de Tribune liet verschijnen, bezegelde als het ware de breuk met zijn gewezen naaste medestanders. Daarmee geraakte hij geleidelijk in een zelf-gewild isolement, dat voor zijn laatste levensperiode, de jaren 1919 tot 1927, kenmerkend is. Ook zijn luttele medestanders in de Nederlandse partij gaf hij op het beslissende ogenblik geen steun. Gaandeweg aanvaardde hij het links-radicale standpunt van Pannekoek, die in het licht 


\section{RECENSIES}

van de ervaringen der Russische revolutie en van het nieuwe radenstelsel elk parlementarisme en elke medewerking aan het bestaande vakverenigingswezen verwierp. Het was een visie waardoor hij niet alleen van de inmiddels tot CP geworden SDP vervreemd geraakte, maar ook met Lenin op gespannen voet kwam. De Liagre Böhl neemt terecht aan dat Gorter in zijn doctrinarisme in iedere machtsvorming van de arbeidersklasse ten slotte een gevaar is gaan zien voor de zuiverheid van het beginsel: zo was het geweest in de jaren van oppositie van de Nieuwe Tijd-groep tegen Troelstra voor 1907, zo ging het in de jaren 1917-1919, toen de Tribunisten de wind in de zeilen kregen, en zo ging het ook ten aanzien van Lenin en de zijnen, getuige vooral Gorter's Open brief aan hem van 1920, waarin ook hij met Troelstra wordt vergeleken.

Volstrekte eenzaamheid is niettemin Gorter's lot in deze jaren toch niet geweest. In de aanvang van 1920 had hij deel aan de werkzaamheden van het Amsterdamse bureau dat een Westeuropees centrum van de nieuwe Internationale moest vormen. Gorter en Pannekoek betoonden zich als voorvechters van de linkse stroming vooral in Duitsland in dit jaar actief. Blijkbaar was zijn gezondheidstoestand geen beletsel voor reizen daarheen en zelfs voor een moeilijke expeditie naar Rusland op het eind van het jaar. Tevergeefs trachtte hij bij die gelegenheid zijn visie tegenover Lenin, die zijn bekende geschrift tegen de linksen het licht 'had doen zien, te rechtvaardigen. Gorter verzandde in wat Trotsky toen en later A. S. de Leeuw genoemd hebben zijn sektarisme. De auteur legt de nadruk op de tegenstrijdigheden in Gorter's argumentatie en op zijn te kort schieten als theoreticus, wat hij, anders dan Pannekoek, ook inderdaad niet geweest is. Dat hij gevoel voor realiteit en nuance ten enenmale miste, is weer iets te veel gezegd: nog in zijn Open brief aan Lenin toont hij althans een open oog voor de verschillen tussen West- en Oost-Europa, zodat hij de bolsjewistische tactiek niet algemeen toepasbaar achtte. Zonder contact met de realiteit had hij ook niet de gevierde propagandist van de Nederlandse arbeidersbeweging kunnen worden in de jaren van haar opgang, toen zijn kristalhelder betoog onuitwisbare indruk maakte op zijn hoorders. Noch zijn elitaire neigingen die aan zijn herkomst verbonden waren, noch zijn hang naar sektarische afzondering die ten slotte in zijn leven de overhand heeft gekregen, kunnen hieraan iets afdoen. Uit deze uitvoerige beschouwingen moge duidelijk geworden zijn hoe stimulerend de lectuur van het boek van De Liagre Böhl voor de belangstellende in de geschiedenis van het Nederlandse socialisme is. De in het bovenstaande gemaakte kritische opmerkingen op een aantal punten zijn dan ook alleen bedoeld als blijk van grote waardering voor deze knap geschreven studie.

A. F. Mellink 


\title{
De vertegenwoordiging van de geërfden in de wateringen van Zeeland bewesten Schelde in de middeleeuwen
}

\author{
C. DEKKER
}

\section{DE ZEEUWSE AMBACHTSHEREN}

Wat de studie van de regionale geschiedenis zo boeiend maakt is de ontdekking van specifieke eigenaardigheden van een bepaald gewest in vergelijking met naburige gebieden. Ook al blijken het in de meeste gevallen bij nader inzien slechts variaties te zijn op een algemeen thema, toch dwingen zij de historicus om dieper te graven en de oorzaak van het eigene op te sporen en in de historische context te verklaren. In de middeleeuwse geschiedenis van Zeeland is een van de meest opvallende verschijnselen de grote macht van de ambachtsheren, die tot uiting komt in de eerste plaats en vanzelfsprekend in het politieke, bestuurlijke en rechterlijke vlak, maar daarnaast in bijna niet mindere mate op het terrein van de kerk en de waterstaat. Die macht is voor de sociaal-economische verhoudingen buiten de (weinige) steden grotendeels bepalend en doet zich zelfs gevoelen in de cultureel-literaire sfeer. Ambachtsheren zelf zijn niet specifiek Zeeuws, maar de grote macht, die zij collectief - een groot aantal onder hen trouwens ook individueel - bezitten, is dat wel. Ook in de naburige gewesten Vlaanderen en Holland trof men ambachtsheren aan en wanneer men even afziet van de term ambacht, plaatselijke heren bekleed met overheidsgezag en in het bezit van de lage rechtsmacht kwamen overal voor. Maar nergens in de wijde omgeving was hun macht zo groot als in Zeeland, nergens vormden zij zoals daar op bepaalde tijdstippen een reële bedreiging voor het grafelijk gezag, nergens was de landsheer in zijn handelingen zo afhankelijk van de medewerking van de lokale heren ${ }^{1}$.

De juridische basis van waaruit de Zeeuwse ambachtsheren opereerden was niet ongewoon groot. Als plaatselijke executieambtenaren van de graaf namen zij in de rechterlijke organisatie van Zeeland een plaats van gewicht in, die in het laatste kwart van de twaalfde eeuw sterk in betekenis toenam door de instelling van lokale schepen vierscharen, voorgezeten door de ambachtsheren. Daarnaast fungeerden zij als inners van de grafelijke belastingen. De sterke positie, die zij zich wisten te verschaffen, is slechts te verklaren tegen de achtergrond van de politieke situatie, waar-

1. Zie voor de karakteristieken van de Zeeuwse ambachten en ambachtsheren C. Dekker, Zuid-Beveland. De historische geografie en de instellingen van een Zeeuws eiland in de middeleeuwen (Assen, 1971) 386-397 en de daar aangehaalde literatuur. 